\title{
Recent transmission of dengue virus and associated risk Facors among residents of Kassala state, eastern Sudan
}

Mawahib H. Eldigail', Hazem A. Abubaker ${ }^{1}$, Fatima A. Khalid², Tajeldin M. Abdallah³, Ibrahim A. Adam', Gamal K. Adam ${ }^{4}$, Rabie A. Babiker ${ }^{4}$, Mohamed E. Ahmed ${ }^{5,6}$, Eltahir M. Haroun ${ }^{7}$ and Imadeldin E. Aradaib ${ }^{1,6^{*}}$

\begin{abstract}
Background: Acute arboviral infections are distributed worldwide including Sudan, and dengue fever (DENV) is not an exception. The virus activity has recently been frequently reported in Kassala State, eastern Sudan. However, an appropriate epidemiological study would be necessary to provide accurate and precise estimates of the magnitude of recent DENV transmission in this area of endemicity.

Methods: In the present investigation, a cross sectional study was conducted to advance beyond the current knowledge of the epidemiology of the disease in Kassala State. The prevalence of the disease was estimated and associated risk factors were determined. Sampled sera were collected and screened for recent dengue transmissionas as determined by DENV-IgM enzyme-linked immunosorbent assay (ELISA). The collection of data for risk assessment was supported by a well designed structured questionnaire.

Results: The prevalence of recent DENV infection was estimated to be (11.42\%). Potential risk factors to DENV seropsitivity include, age $(\mathrm{OR}=3.24, \mathrm{Cl}=1.81-5.77, \mathrm{p}$-value $=0.001)$; low income $(\mathrm{OR}=3.75, \mathrm{Cl}=1.57-8.93, \mathrm{p}$-value $=$ 0.027); mosquito control ( $\mathrm{OR}=4.18, \mathrm{Cl}=2.33-7.51$, $\mathrm{p}$-value $=0.004)$; and localities.

Conclusion: The present study showed a high rate of circulating DENV IgM antibodies among the participants of the study (11.42\%), suggesting recent transmission of DENV in Kassala State, eastern Sudan. The frequent occurrence of DENV infections necessitates the need for improved surveillance programs and prevention measures to combat this important arboviral disease in Sudan.
\end{abstract}

Keywords: Epidemiology, Survey, Dengue virus, ELISA, Sudan

\footnotetext{
* Correspondence: aradaib@yahoo.com

1 Molecular Biology Laboratory (MBL), Department of Clinical Medicine,

Faculty of Veterinary medicine, University of Khartoum, P.O. Box 32,

Khartoum North, Sudan

${ }^{6}$ Zamzam Unit for Medical Research (ZUMR), Vectore Borne and Zoonotic Diseases Research Laboratory, Zamzam University College, Khartoum, Sudan

Full list of author information is available at the end of the article
}

(c) The Author(s). 2020 Open Access This article is licensed under a Creative Commons Attribution 4.0 International License, which permits use, sharing, adaptation, distribution and reproduction in any medium or format, as long as you give appropriate credit to the original author(s) and the source, provide a link to the Creative Commons licence, and indicate if changes were made. The images or other third party material in this article are included in the article's Creative Commons licence, unless indicated otherwise in a credit line to the material. If material is not included in the article's Creative Commons licence and your intended use is not permitted by statutory regulation or exceeds the permitted use, you will need to obtain permission directly from the copyright holder. To view a copy of this licence, visit http://creativecommons.org/licenses/by/4.0/ The Creative Commons Public Domain Dedication waiver (http://creativecommons.org/publicdomain/zero/1.0/) applies to the data made available in this article, unless otherwise stated in a credit line to the data. 


\section{Background}

Dengue fever (DF) is caused by dengue virus (DENV), a positive-sense single stranded RNA virus of the genus Flavivirus in the family Flaviviridae [1,2]. DF has been reported as one of the most important arboviral disease in many parts of the world including the Sudan [3-5]. DENV is spreading very rapidly resulting in emerging infections world-wide [6]. The high incidence of the disease has become of great concern to the public health officers worldwide [7-9]. In the recent years, DENV has spread all over the Sudan resulting in frequent occurrence of sporadic cases and multiple outbreaks [10-13]. The major economic losses caused by DENV infections in Sudan are almost exclusively confind to the Kassala state, eastern Sudan [10, 11, 14-16]. DENV activity usually varies from frequent sporadic cases to large explosive outbreaks. Clinical presentations of infected patients varies from mild fever to involvement of the circulatory system resulting in hemmorhagic manufistation with subsequent development of a more severedengue hemorrhagic fever (DHF). The clinical hemmorahagic disease leads to substantial increase in vascular permeability, which leads to dengue shock syndrome (DSS) followed by death $[17,18]$. It is well documented that four DENV serotypes (DENV-1, DENV-2, DENV-3 and DENV-4) are circulating globally. DENV serotypes 1, 2 and 3 were reported to be endemic in some parts of the country [19-21]. However, DENV-4 is yet to be reported in Sudan. Several epidemic cycles of dengue have been recorded in the eastern States including, the Red Sea and Kassala [10, $11,14,20]$. In the last few years, DENV activity has also been documented in the western part of the Sudan including the States of Darfur and Kordufan. DENV-1 and DENV3 were associated with the disease outbreaks in these States [22, 23]. In 1986, an outbreak of acute febrile disease caused by DENV-1 and DENV-2 was reported for the first time the Red Sea State, Sudan. Very recently, we reported on an exceptionally high prevalence (47.6\%) of DENVspecific IgG in El-Gadarif State, eastern Sudan, where the disease has never been recorded before [24]. The State of El-Gadarif has several agricultural schemes and is boardring Kassala State to the south west side. In Sudan, several seroepidemiological studies were conducted to evaluate previous DENV infections by detection of DENV IgG antibodies. However, only two studies were conducted to evaluate recent transmission of DENV in the locality of Kassala and not the whole State. A previous seroepidemiological survey for DENV IgM, using Panbio (DF IgG and IgM) ELISA kits, reported a very low prevalence of $0.6 \%$ among residents of Kassala locality [16]. However, the underestimated prevalence of DENV IgM was attributed to the limitation of the ELISA assay to accurately detect IgM in sera from the study participants. The fact that the survey was conducted in the low transmission season of the year has also contributed to the low recent DENV transmission in the State. An appropriate epidemiological study would be necessary to provide more precise estimates of the magnitude of recent DENV transmission. On the other hand, a very high prevalence of $71.7 \%$ was reported among febrile patients admitted to Kassala Hospital during an outbreak of the disease, 2010 [14]. The exceptionally high prevalence of DENV IgM (71.7\%) could be justified as the study was conducted during disease outbreak among symptomatic participants. DENV is endemic in the Sudan and the virus is probably actively circulating throughout the year, with a peak incidence between September and November, which coincides with the high rainy season. The detection of DENV IgM/ IgG antibodies and subsequent recovery of the virus from infected patients have been reported in eastern regions of the Sudan [10,11, 19-22]. Recently, high incidence of dengue fever has been reported among residence of Kassala state as witnessed by frequent DENVsporadic cases and occuasionalmultiple outbreaks [19, 25]. Therefore, improved surveillance systems should be implemented to obtain comprehensive information on the epidemiology of DENV in Sudan. It is worth mentioning that implementation of improved surveillanceshould facilitate prediction and detection of recent infections and subsequent understanding of the ecology and biology of the virus, and the molecular epidemiology of the disease in this area of endimicity. From a public health prospective, we believe an accurate estimation of prevalence of new cases of DENV infections and identification of the associated risk factors are urgently needed. In the present investigation, serum samples were collected during the transmission season of DENV. In addition, participants from all localities of Kassala state were included in the study to provide a more accurate estimate of recent transmission of DENV. We anticipated that this study would be expected to provide a reliable and accurate epidemiological data, which assists in facilitating the control of the disease and prevent an expected DENV outbreak among residents of Kassala State, Sudan.

\section{Methods \\ Study area}

The present cross-sectional study was conducted in Kassala State, one of the poorest regions in Sudan, during the period between August, 2017 and May, 2018. Refugees and internally displaced population are hosted in this state. Most of the populations in the rural areas suffer of acute poverty and limited development prospects. The residentmigrated mainly from the war and rural areas affected by drought and desertification where the environmental conditions have continued to deteriorate over the years. The state experienced poverty and food insecurity that affect the region in the recent years. The state has an area of $36,710 \mathrm{~km}^{2}$ and an estimated population of approximately 1,400,000. Kassalastate is bordered 
by Eritrea and Ethiopia to the east, the Red Sea state to the north, Khartoum and the River Nile states to the west and the Gadarif state to the south west. The State is located between latitudes $15.8058^{\circ} \mathrm{N}$ and longitudes $35.5658^{\circ} \mathrm{E}$ in the semi-desert tropics. The climate is hot and rainy in summer but cold in winter. The fall extends from July to November, with an average $268 \mathrm{~mm}$ annual rainfall. The average annual temperature is $29.2^{\circ} \mathrm{C}$. Kassala state is composed of 11 localities, which include Kassala, Rural Kassala, West Kassala, New Halfa, Atbara River, Hamashkorieb, Elgirba, Delta North, Aroma, Talkuk, and Wad Elheiliew as illustrated in Fig. 1.

\section{Study design, specimen collection and preparation}

The blood samples were collected during the months of August to November, 2017. High infection rates occur during these months of the year, which coincise with the rainy season. Recent DENV transmission was determined as monitored by detection of DENV IgM antibodies. A cross sectional study was conducted to estimate the incidence rate of recent DENV-infections as judgedby detection of the specific IgM antibodies and to determine the potential risk factors associated with the disease. The participants for the study were selected from all 11 localities of Kassala State using a multi-stage cluster sampling technique was used to select the study participants [26]. In the first stage, the clusters, which were equivalent to a Popular Administrative Units were selected using the probability proportionate. In the second stage, households were selected using a systematic random sampling technique. Details of the selection procedure were similar to that described in a previous report [24]. Blood samples were collected from the participants, and sera were separated and kept frozen at $-20^{\circ} \mathrm{C}$ until used for the detection of DENV-specific IgM antibodies by the enzyme-Linked Immunosorbent Assay (ELISA).

\section{Questionnaire}

All participants from the above 11 localitie, targeted in this study, were subjected to interviews to obtain some information related to the risk assessment. A welldesigned structured questionnaire was employed for this purpose. The questionnaire, covers socio-demographic characteristics including; age (young age, $\geq 5$ and $<18$ years-old; old age $>18$ year-old); gender (male and female); disease awareness (yes, no); work (employed, unemployed); education (illiterate, primary, secondary, University); household income which includes, low income (less than 2000 Sudanese Ginah (SDG), medium income (more than 2000 but less than 3000 SDG) and high income (more than 3000 SDG); mosquito net use (present or absent), and mosquito control (practiced or not practiced). The mosquito control includes the use of insecticides and mosquito nets. A Supplementary copy of the questionnaire is attached to the manuscript as a an additional file for clarity of the study (Additional file 1).

\section{Sample size}

In a previous report the prevalence of DEMV-IgM seropositivity, during disease outbreak in Kassala State, was reported to be as high as $71.7 \%$ among patient admitted to Kassala hospital [14]. The second report showed a very low prevalence of $(0.6 \%)$ as the study involved participants during dry season of the year where vector transmission is very rare [16]. The two seroepidemiological surveys were conducted in the locality of Kassala. None of the 2 studies involved participants from all localities of the State. In the present study, representative serum samples were obtained from participants of all 11 localies of Kassala. In addition, the serum samples were collected during the transmission season of DENV to obtain an accurate estimation of recent transmission. Because of the high variation between the two studies, we assumed the DENV-IgM seroprevalence to be 50\%. The required sample size at $95 \%$ confidence and $50 \%$ prevalence and 0.04 absolute precision was calculated to be 600. A design effect of 2 and a non-response rate of $10 \%$ were considered to adjust for the sampling technique. The formula for the calculation of the sample size was applied as described by Dean et al. [27]. study participants were selected from all the 11 localities of Kassala State of DENV.

\section{Study inclusion and exclusion criteria}

Any individual of both gender aged $\geq 18$ years-old was included in this study. The samples were collected from symptomatic population. The symptoms include fever and rash for the last 5 days with or without hemorrhagic manifestations, vomiting, headache, and joint pain. Participants who are not residing in Kassala state for the previous 6 months including visitors and travellers were excluded from the study.

\section{Ethics approval and consent to participate}

The ethical clearance for this study was kindly provided by the Ethics committee, Kassala State Ministry of Health, Sudan. Written consent for the purpose of this study was obtained from all participants and the objectives of the study were made clear prior to obtaining the informed consent.

\section{Enzyme linked Immunosorbent assay}

The ELISA assay was performed using a commercially available IgM DENV ELISA Kit (Euroimmun AG, Luebeck, Germany), in accordance with the manufacturer's 


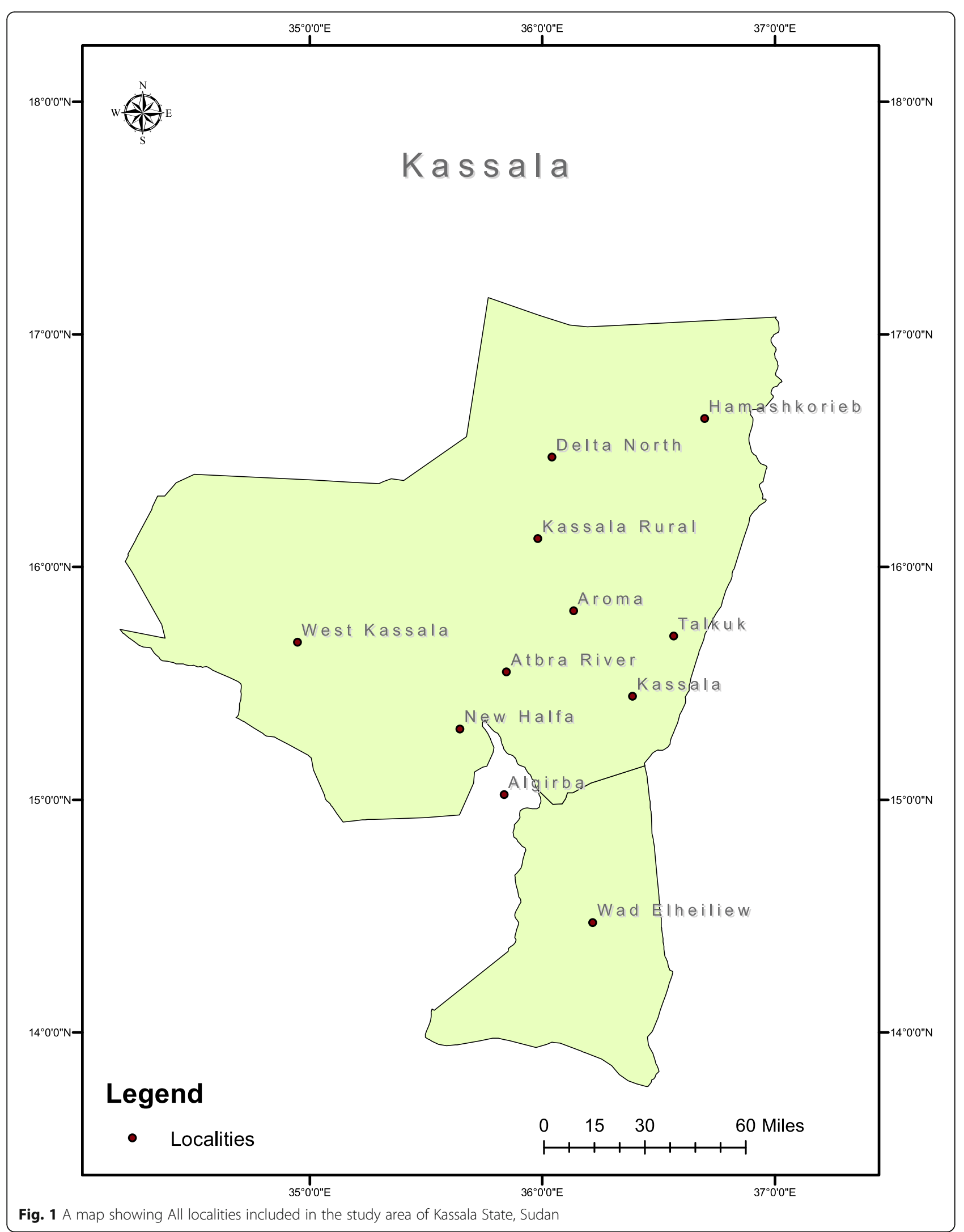


Table 1 Univariate analysis for the association between potential risk factors and DENV infection among residents of Kassala State, Sudan, using chi-square test ( $\mathrm{X} 2)$

\begin{tabular}{|c|c|c|c|c|c|}
\hline Risk factors & Cases tested & Cases affected (\%) & df & $x^{2}$ & $p$-value \\
\hline Locality & & & 10 & 19.37 & 0.044 \\
\hline Kassala & 105 & $8(7.6 \%)$ & & & \\
\hline R. Kassala & 84 & $11(13.1 \%)$ & & & \\
\hline W. Kassala & 70 & $12(17.1 \%)$ & & & \\
\hline New Halfa & 83 & 7 (8.4\%) & & & \\
\hline Atbara River & 70 & $9(12.9 \%)$ & & & \\
\hline Hamashkorieb & 53 & $6(11.3 \%)$ & & & \\
\hline Elgirba & 49 & $7(14.3 \%)$ & & & \\
\hline Delta North & 50 & $1(2.0 \%)$ & & & \\
\hline R. Aroma & 22 & $(00.0 \%)$ & & & \\
\hline Talkuk & 61 & $7(11.5 \%)$ & & & \\
\hline Wad Elheiliew & 54 & $12(22.2 \%)$ & & & \\
\hline Age & & & 1 & 17.06 & 0.001 \\
\hline young & 309 & $18(5.87 \%)$ & & & \\
\hline Old & 392 & $62(15.8 \%)$ & & & \\
\hline gender & & & 1 & 1.16 & 0.281 \\
\hline female & 320 & $32(10.6 \%)$ & & & \\
\hline male & 381 & 48 (12.6\%) & & & \\
\hline Education & & & 4 & 1.13 & 0.897 \\
\hline illiterate & 177 & $19(10.7 \%)$ & & & \\
\hline primary & 233 & $30(12.9 \%)$ & & & \\
\hline secondary & 146 & $14(9.6 \%)$ & & & \\
\hline university & 92 & $11(12 . \%)$ & & & \\
\hline informal study & 53 & $6(11.3 \%)$ & & & \\
\hline Income & & & 2 & 3.98 & 0.136 \\
\hline low & 440 & $56(12.7 \%)$ & & & \\
\hline medium & 146 & $17(11.6 \%)$ & & & \\
\hline high & 115 & $7(6.1)$ & & & \\
\hline Work & & & 1 & 0.05 & 0.809 \\
\hline unemployed & 298 & $33(11.1 \%)$ & & & \\
\hline employed & 403 & $47(11.7 \%)$ & & & \\
\hline Disease awareness & & & 1 & 3.38 & 0.06 \\
\hline no & 645 & 75 (12.3\%) & & & \\
\hline yes & 56 & $5(5.6 \%)$ & & & \\
\hline Mosquito net use & & & 1 & 6.16 & 0.013 \\
\hline no & 342 & $43(12.3 \%)$ & & & \\
\hline yes & 359 & 37 (10.6\%) & & & \\
\hline Mosquito control & & & 1 & 12.38 & 0.001 \\
\hline No & 313 & $126(40.3 \%)$ & & & \\
\hline yes & 388 & 205 (53.6\%) & & & \\
\hline
\end{tabular}

specifications. The test samples were considered positive if the optical density was $\geq 50 \%$ of the mean of the negative controls.

\section{Statistical analyses}

The data were double checked before entry into the computer. Univariable analysis using Chi-square $\left(\mathrm{x}^{2}\right)$ test and 
Table 2 Multivariate analysis, using logistic regression model, for significant association ( $p<0.05$ ) between risk factors and dengue fever infections among residents of Kassala State, Sudan

\begin{tabular}{llll}
\hline Risk factors & OR & $95 \% \mathrm{C} \mathrm{I}$ & P-Value \\
\hline $\begin{array}{l}\text { Age } \\
\text { Young }\end{array}$ & Ref & & \\
Old & 3.24 & $1.81-5.77$ & 0.001 \\
$\begin{array}{l}\text { Income } \\
\text { high }\end{array}$ & Ref & & \\
low & 3.75 & $1.57-8.93$ & 0.027 \\
Mosquito control & & & \\
yes & Ref & & \\
no & 4.18 & $2.33-7.51$ & 0.004 \\
Locality & & & \\
Aroma & Ref & & 0.045 \\
W. Kassala & 2.81 & $1.07-7.88$ & 0.030 \\
Wad Elheliew & 3.07 & $1.08-8.36$ & \\
\hline
\end{tabular}

multivariable analysis using logistic regression were calculated. Final results for risk factors were tabulated as odd ratios (OR) with 95\% confidence intervals (C.I). Significant association between the dengue fever seropositivity and associated risk factorswhere considered when $p<0.05$ is obtained. Statistical analysis using SPSSStatistical packageversion 21.0) was applied to determine thee prevalence and the potential risk factors. Details of statistical analysis were described else where by Eldigail et al. [24].

\section{Results}

DENV-specific IgM ELISA assay was employed for detection of early antibody response to recent infection. Serum samples from al1 participants were tested in duplicates for the presence of DENV infection. Recent infection to DENV, as determined by DENV-specific IgMantibodies, was detected in $80(11.42 \%)$ out of 701 participants using the ELISA assay. The highest rate of DENV seropositivity was recorded in the locality of Wad Elheiliew (22.2\%) whereas the lowest rate was reported in Delta North (2.0\%). However, Rural Aroma was found to be free of recent DENV infection (0.00\%). Initially, the univariate analysis indicated that six risk factors with $\mathrm{p}$ - value $<0.25$ (two tailed; $\alpha=0.25$ ) were significantly associated with DENV-antibodies as calculated in the $\mathrm{X}^{2}$ test. These risk factors included locality $(\mathrm{p}-$ value $=$ $0.044)$, age $(p$-value $=0.001)$, income $(p$ - value $=0.136)$, disease awareness $(p$-value $=0.06)$, mosquito net use $(p$ value $=0.013)$, and mosquito control practice $(p$-value $=$ $0.001)$. The results of the univariate analysis are presented in (Table 1). Final model of multivariate analysis using logistic regression was applied to exclude confounding factors, which could be encountered in the initial results of univariate analysis. The final results using logistic regression indicated that only four potential independent risk factors were found to be significantly associated with DENV infection. These potential risk factors included, age $(\mathrm{OR}=3.24, \mathrm{CI}=1.81-5.77, p$ value $=0.001)$; low income $(\mathrm{OR}=3.75, \mathrm{CI}=1.57-8.93$, $\mathrm{p}$ value $=0.027)$; mosquito control $(\mathrm{OR}=4.18, \mathrm{CI}=2.33$ 7.51 , p-value $=0.004)$; and localities. The two localities associated with high DENV serpositivity included West Kassala $(\mathrm{OR}=2.81$, CI: $1.07-7.88, p$ value $=0.045)$ and Wadelheliew $(\mathrm{OR}=3.07, \mathrm{CI}: 1.08-8.36, p$-value $=0.03)$. The results of the significant association between DENV seropositivity and potential riskfactors in the final model are presented in (Table 2).

\section{Discussion}

Dengue virus (DENV) is a single stranded RNA arbovirus of the geus Flavivirus in the family Flaviviridae. DENV causes an acute febrile illness, which may develop in clinical hemorrhagic manifestation followed by shock [2]. The surge of construction of new cities along the River Nile and the Red Sea has let to urbanization in different parts of Sudan. In addition to urbanization, climate changes and increased human movements have contributed significantly to the global spread of DENV $[4,5,9,28]$. The prevalence rate of DENV seropositivity in Kordufan and Darfur State of western Sudan were reported to be 27.7 and $15.7 \%$, respectively [22, 23]. Interestingly, the present study showed a high prevalence of IgM antibodies of recent DENV infection among the residents of Kassala State (11.42\%), suggesting recent transmission of DENV during the period of the study. Older participants are at 3 times higher at risk compare to younger age group $(\mathrm{OR}=3.24, \mathrm{CI}=1.81-5.77, p$ value $=0.001$ ). Most of the participants exposed to recent dengue fever are over 18 years old. In addition, the present study indicated that DENV seropositivity increased among low-income participants. Low income residents were almost 4 times higher at risk compared to high income residents $(\mathrm{OR}=3.75, \mathrm{CI}=1.57-8.93, p$ value $=0.027$. A considerable number of low income residents conistitutes refugees and internally displaced population. Most of the residents in Kassala State suffer acute poverty and limited development prospects. In addition, the State also experienced food insecurity, which was reflected very badly on the residents welfare in the recent years. The majority of the populations work in private sectors with minimum payment and others are unemployed. This cituation resulted in poor socioeconomic status, which contributed to high seropositivity to DENV. It is suggested that poor socioeconomic status of the population would result in contamination of the environment with infectious diseases and provide suitable habitat for breeding of mosquito vectors, Aedes aegypti. The present study also showed 
significant association beteen DENV seropositivity and mosquito control of the primary vector $(\mathrm{OR}=4.18, \mathrm{CI}=$ 2.33-7.51, $p$-value $=0.004$ ). The leve of DENVseropositivity was significantly reduced by at least four times when the application of insecticides was practiced. It should also be noted that Kassala State has several agricultural schemes and irrigation projects, which favour the environment condition for endemicity of DENV. In addition, the State is usually affected by the annual floods of El-Gash regional river during the rainy season. These environmental conditions provides suitable habitat for the breeding of the mosquito vector. The control of dengue vector is necessary to prevent the spread of the virus and to reduce the critical impact of disease burden in Sudan and the African continent at large. Future entomological studies would be required to determine the distribution of the vector in Sudan to facilitate control and management of the disease. There was also positive association between DENV seropositivity and the localities of WestKassala (OR $=2.81, \mathrm{CI}: 1.07-7.88, p$ value $=0.045)$; and WadElheliew $(\mathrm{OR}=3.07, \mathrm{CI}$ : 1.08 $8.36 p$-value $=0.03$ ). This is probably due to high rain fall in these localities, which provide suitable habitat for the mosquito vector that transmits the disease. Residents of of Wad Elheliewlocality are at 3 times higher at risk of becoming infected with DENV compared to other localities, suggesting increased DENV endemicity of this locality. On the other hand, the locality of Rural Aroma was found to be free of recent DENV infection $(0.00 \%)$. This could be attributed to the hot and dry weather, which does not provide a suitable habitat for the breeding of the mosquito vector. However, it should also be noted that the lowest number of samples was collected from participants of this locality. It should be taken into consideration that Kassala State shares boarder with Ethiopia and Eretria to the east side of Sudan. Increased human movement due to international trade has recently been observed in the region. It is, therefore, suggested that movementof DENV is likely to occur between these countries in east central Africa. How DENV travels is unclear but probably involves movement of infected mosquitoes via commercial trade or travel of viremic patients $[8,28-30]$. It is also possible that DENV spreads to eastward across the Red Sea into Saudi Arabia through the winds. More sequencing data of DENV isolated in the region and subsequent phylogenetic analysis would be required to identify the DENV serotypes and to determine the virus genetic lieages circulating the region. In Sudan, there is no wellestablished active dengue surveillance system and physicians do not usually consider dengue during clinical presentation and differential diagnosis. Circulation of dengue virus serotype 2 was reported to be associated with disease outbreak in Kassala State, 2017 [17].
However, none of the remaining serotypes were reported in this State. More than one DENV serotypes are are belived to be co-existing in the State. Further study would be required to confirm this assumotion. Severe cases of dengue hemorrhagic fever are usually associated with the presence of multiple serotypes of DENV in areas of endemicity $[17,18,31]$. Therefore, further studies are needed to provide some information on virological aspect and molecular biological detail of DENV in Kassala State. The study suggested that an established diagnostic facility and appropriate control program should be considered as a top priorityto combat this important arboviral infection [32,33].

\section{Limitation of the study}

The present study provides important information regarding the prevalence and risk factors of recent transmission of DENV in Kassala State, Sudan. Despite the fact that this is the first report on sero-prevalence of dengue in all localities representing Kassala State, during the transmission season of the disease, some limitations were recorded for careful consideration in the future. One of the limitations of the study is that the seropositivity was assessed by detecting DENV IgM antibody levels. It is well documented that detection of IgM is useful in an epidemiological survey to identify recent infections. However, the ELISA IgM antibodies can crossreact with other flaviviruses. Members of flavivirus serogroup, other than DENV, have not been reported in eastern part of Sudan including Kassala State. At the same token, negative results will not exclude the disease, as the production of DENV IgM requires at least 1 week window period post infection. We recognized that DENNS1 ELISA assay is useful to eliminate the possibility of cross reaction with related flaviviruses. However, DENVNS1 ELISA can detect positive cases at about the first 2 weeks of infection. Serum samples collect at a later stage are likely to be missed during the performance of the assay resulting in false negative results. Therefore, it should be noted that employment of different assays for screening of recent DENV transmission would change the interpretation of the results substantially given their different window of detection. Virus serum neutralization test would be more appropriate to identify DENV serotypes and to eliminate the possibility of cross reaction. In addition, virus isolation attempts and subsequent molecular characterization studies were not conducted in this study. Future studies should consider the detection and identification of circulating DENV serotypes and associated genotypes in this region of the African continent. Further investigations should be conducted in the future to overcome the limitations of the study. 


\section{Conclusions}

Our study illustrates recent DENV transmission during the rainy season of the year resulting in high prevalence of $11.42 \%$ in Kassala State of eastern Sudan. Age, low income, mosquito control and localities showed significant association with DENV IgM seropositivity. It is suggested that, virus isolation attempts should be conducted to identify DENV serotypes and associated genotypes circulating in Sudan. In addition, generation of whole viral genome sequences and subsequent phylogenetic relatedness would be advantageous in tracing the movement of the virus in this region of the African continent. Differentia diagnosis for DENV should be considered when clinical presentation is conducted in a patient with symptoms indicative of acute febrile illness. The frequent occurrence of recent DENV infections necessitates the need for improved surveillance programs and prevention measures to combat this important arboviral disease in Kassala State, Sudan.

\section{Additional File}

Additional file 1. A Supplementary copy of the questionnaire is attached to the manuscript as a an additional file for clarity of the study (Additional file. 1) showing the data employed for the identification of the risk factors associated with Recent transmission of dengue virus among residents of Kassala State, Eastern Sudan.

\section{Abbreviations}

DEN: Dengue; DEN-V: Dengue virus; Ig G: Immunoglobulin G; Ig M: Immunoglobulin M; ELISA: Enzyme-linked immunosorbent assay; RTPCR: Reverse transcriptase polymerase chain reaction; MI: Microliter; $\mathrm{Cl}$ : Confidence interval; OR: Odd ratio; HRP: Horse radish peroxidase

\section{Acknowledgments}

This study was made possible by the invaluable assistance provided by the medical staff from the different localities of Kassala states, Sudan. We thank Abdall M. FadIEImoula for technical assistance, BadreldinMirghani for his assistance in creating the Sudan map, and Mukhtar Abu-Samrafor his editorial assistance. This study received partial financial support from the Directorate of Scientific Research and Cultural relations, University of Khartoum, and CDC.

\section{Authors' contributions}

$M H E$, GKA, RAB, FK, IAA helped with the collection of blood samples, extracted the DNA, optimized the polymerase chain reaction-based detection assay, editing of sequences and helped with the manuscript writing. MEA, analyzed the ELISA results; EMH, HAA, TMA, designed the experiment and helped with the preparation of the final manuscript. IEA designed the experiment, help with data analysis and prepared the final manuscript. All authors read and approved the final version of the manuscript.

\section{Funding}

This study was financially supported by the Ministry of Higher Education and Scientific Research, Republic of the Sudan, grant number. (MHE-competitive grants-5). The funding body has no role in the design of the study and collection, analysis, and interpretation of data and in writing the manuscript.

\section{Availability of data and materials}

Data and materials are available upon request from the corresponding author.

\section{Ethics approval and consent to participate}

The study protocol was approved by the Ethics Committee of, Al-Neelain University, Khartoum, Sudan. Participation was on a voluntary basis, and the residents were randomly selected and a written informed consent was obtained from all participants after explanation of the study objectives and prior to the study procedures and blood collection. The risk factors information was obtained from the residents through the structured questionnaire form, permitting the use of their blood samples for diagnostic and research purposes.

\section{Consent for publication}

Not applicable.

\section{Competing interests}

The authors declare that they have no competing interests. The result of this study does not reflect the opinion of the funding sources. All authors have read and approved the final version of this manuscript.

\section{Author details}

${ }^{1}$ Molecular Biology Laboratory (MBL), Department of Clinical Medicine, Faculty of Veterinary medicine, University of Khartoum, P.O. Box 32, Khartoum North, Sudan. ${ }^{2}$ Department of Microbiology, Faculty of Science, University of Kassala, Kassala, Sudan. ${ }^{3}$ Department of Internal Medicine, Faculty of Science, University of Kassala, Kassala, Sudan. ${ }^{4}$ Department of Medical laboratory Sciences, Faculty of Medicine, University of Elgadarif, Elgadarif, Sudan. ${ }^{5}$ Deanship of Scientific Research, Alneelain University, Alneelain, Sudan. ${ }^{6}$ Zamzam Unit for Medical Research (ZUMR), Vectore Borne and Zoonotic Diseases Research Laboratory, Zamzam University College, Khartoum, Sudan. 'Deanship of Scientific Research, Moghtaribeen University of Africa, Khartoum, Sudan.

Received: 19 September 2019 Accepted: 5 April 2020

Published online: 19 April 2020

\section{References}

1. World Health Organization. Dengue Guidelines for Diagnosis, Treatment, Prevention and Control: New Edition. World Health Organization; Geneva, Switzerland: 2009.

2. Simmons CP, Farrar JJ, van VinhChau N, Wills B. Dengue N Engl J Med. 2012; 366:1423-32.

3. Bhatt S. GethingPW., Brady OJ, Messina JP, Farlow AW, Moyes CL, drake JM, Brownstein JS, Hoen AG, Sankoh O, et al. the global distribution and burden of dengue. Nature. 2013;496:504-7.

4. Brady OJ, Gething PW, Bhatt S, Messina JP, Brownstein JS, Hoen AG, Moyes $\mathrm{CL}$, Farlow AW, Scott TW, Hay SI. Refining the global spatial limits of dengue virus transmission by evidence-based consensus. PLoS Negl Trop Dis. 2012; 6:e1760.

5. Guzman MG, Halstead SB, Artsob H, Buchy P, Farrar J, Gubler DJ, Hunsperger E, Kroeger A, Margolis HS, Martínez E, et al. Dengue: a continuing global threat. Nat Rev Microbiol. 2010;8:S7-S16.

6. Van Kleef E., Bambrick H., Hales S. The geographic distribution of dengue fever and the potential influence of global climate change. [(accessed on 11 February 2017)]; Available online: http://eprints.qut.edu.au/103224/.

7. Tatem AJ, Hay SI, Rogers DJ. Global traffic and disease vector dispersal. Proc Natl Acad Sci U S A. 2006;103:6242-7.

8. Wilder-Smith A., Gubler D.J. Geographic expansion of dengue: the impact of international travel. Med Clin2008:92:1377-1390.

9. Gubler DJ. Dengue, urbanization and globalization: the unholy trinity of the 21st century. Trop Med Health. 2011:39:3-11.

10. Malik A, Earhart K, Mohareb E, Saad M, Saeed M, Ageep A, Soliman A. Dengue hemorrhagic fever outbreak in children in Port Sudan. J Infect Public Health. 2011;4:1-6.

11. Seidahmed OM, Siam HA, Soghaier MA, Abubakr M, Osman HA, AbdElrhman LS, Elmagbol B, Velayudhan R. Dengue vector control and surveillance during a major outbreak in a coastal Red Sea area in Sudan. East Mediterr Health J. 2012;18:1217-24.

12. Soghaier MA, Himatt S, Osman KE, Okoued SI, Seidahmed OE, Beatty ME, Elmusharaf K, Khogali J, Shingrai NH, Elmangory MM. Cross-sectional community-based study of the socio-demographic factors associated with the prevalence of denque in the eastern part of Sudan in 2011. BMC Public Health. 2015;15:558. 
13. Elduma AH, Osman WM. Dengue and hepatitis E virus infection in pregnant women in Eastern Sudan, a challenge for diagnosis in an endemic area. Pan Afr Med J. 2014;19:391.

14. Abdallah TM, Ali AAA, Karsany MS, Adam I. Epidemiology of dengue infections in Kassala. Eastern Sudan J Med Virol. 2012;84:500-3.

15. Adam I, Jumaa AM, Elbashir HM, Karsany MS. Maternal and perinatal outcomes of dengue in PortSudan. Eastern Sudan Virol J. 2010;7:153.

16. Himatt S, Osman KE, Okoued SI, Seidahmed OE, Beatty ME, Soghaier MA, Elmusharaf K. Sero-prevalence of dengue infections in the Kassala state in the eastern part of the Sudan in 2011. J Infect Public Health. 2015:8:487-92.

17. Gubler DJ. Epidemic dengue/dengue hemorrhagic fever as a public health, social and economic problem in the 21st century. Trends Microbiol. 2002;10: 100-3.

18. Humayoun MA, Waseem T, Jawa AA, Hashimi MS, Akram J. Multiple dengue serotypes and high fresquency of dengue hemorrgahic fever at twotertiary care hospitals in Lahore during the 2008 dengue virus outbreak inPunjab. Pakistan Int J Infect Dis. 2010;14(suppl. 3):54-9.

19. Hamid Z, Hamid T, Alsedig K, Abdallah T, Elaagip A, Ahmed A, Khalid F, Abdel HM. Molecular investigation of dengue virus serotype 2 circulation in Kassala state. Sudan Jpn J Infect Dis. 2019;72:58-61.

20. Seidahmed OM, Hassan SA, Soghaier MA, Siam HA, Ahmed FT, Elkarsany MM, Sulaiman SM. Spatial and temporal patterns of denque transmission along a Red Sea coastline: a longitudinal entomological and serological survey in Port Sudan city. PLoSNegl Trop Dis. 2012;6:e1821.

21. Hyams KC, Oldfield EC, Scott RM, Bourgeois AL, Gardiner H, Pazzaglia G, Moussa M, Saleh AS, Dawi OE, Daniell FD. Evaluation of febrile patients in Port Sudan, Sudan: isolation of dengue virus. Am J Trop Med Hyg. 1986; 35(4):860-5.

22. Soghaier MA, Mahmood SF, Pasha O, Azam SI, Karsani MM, Elmangory MM, Elmagboul BA, Okoued SI, Shareef SM, Khogali HS, Eltigai E. Factors associated with dengue fever lgGsero-prevalence in South Kordofan state, Sudan,in 2012: reporting prevalence ratios. J Infect Public Health. 2014;7:54-61.

23. Ahmed A, Elduma A, Magboul B, Higazi T, Ali Y. The first outbreak of dengue fever in greater Darfur. Western Sudan Trop Med Infect Dis. 2019;1, 4(1).

24. Eldigail MH, Adam GK, Babiker RA, Khalid F, Adam IA, Omer OH, Ahmed ME, Birair SL, Haroun EM, AbuAisha H, Karrar AE, Abdalla HS, Aradaib IE. Prevalence of dengue fever virus antibodies and associated risk factors among residents of El-Gadarif state, Sudan. BMC Public Health. 2018; 18(1):921.

25. Adam A, Schüttoff T, Reiche S, Jassoy C. High seroprevalence of dengue virus indicates that dengue virus infections are frequent in central and eastern Sudan. Tropical Med Int Health. 2018;23(9):960-7.

26. Martin SW, Meek AH, Willeberg P. Veterinary epidemiology: principles and methods. Ames: lowa State University Press; 1987. p. 45.

27. Dean AG, Sullivan KM, Soe MM. OpenEpi: open source epidemiologic statistics for public health, version 3.01. 2010. www.OpenEpi.com.

28. Wesolowski A, Qureshi T, Boni MF, Sundsøy PR, Johansson MA, Rasheed $\mathrm{SB}$, Engø-Monsen $\mathrm{K}$, Buckee CO. Impact of human mobility on the emergence of dengue epidemics in Pakistan. Proc Natl Acad Sci U S A. 2015;112:11887-92

29. Cummings DAT, Irizarry RA, Huang NE, Endy TP, Nisalak A, Ungchusak K, Burke DS. Travelling waves in the occurrence of dengue haemorrhagic fever in Thailand. Nature. 2004;427:344-7.

30. Stoddard ST, Morrison AC, Vazquez-Prokopec GM, Soldan VP, Koche TJ, Kitron U, Elder JP, Scott TW. The Role of Human Movement in the Transmission of Vector-Borne Pathogens. PLoS Negl. Trop. Dis. 2009;3:e481.

31. Endy TP, Anderson KB, Nisalak A, Yoon I-K, Green S, Rothman AL, Thomas SJ, Jarman RG, Libraty DH, Gibbons RV. Determinants of Inapparent and symptomatic dengue infection in a prospective study of primary school children in KamphaengPhet. Thailand PLoSNegl Trop Dis. 2011;5:e975

32. McCarthy MC, Haberberger RL, Salib AW, Soliman BA, El-Tigani A, Khalid IO, Watts DM. Evaluation of arthropod-borne viruses and other infectious disease pathogens as the causes of febrile illnesses in the Khartoum Province of Sudan. J Med Virol. 1996;48(2):141-6.
33. Watts DM, el-Tigani A, Botros BA, Salib AW, Olson JG, McCarthy M, Ksiazek TG. Arthropod-borne viral infections associated with a fever outbreak in the northern province of Sudan. J Trop Med Hyg. 1994;97(4):228-30.

\section{Publisher's Note}

Springer Nature remains neutral with regard to jurisdictional claims in published maps and institutional affiliations.
Ready to submit your research? Choose BMC and benefit from:

- fast, convenient online submission

- thorough peer review by experienced researchers in your field

- rapid publication on acceptance

- support for research data, including large and complex data types

- gold Open Access which fosters wider collaboration and increased citations

- maximum visibility for your research: over $100 \mathrm{M}$ website views per year

At $\mathrm{BMC}$, research is always in progress.

Learn more biomedcentral.com/submissions 